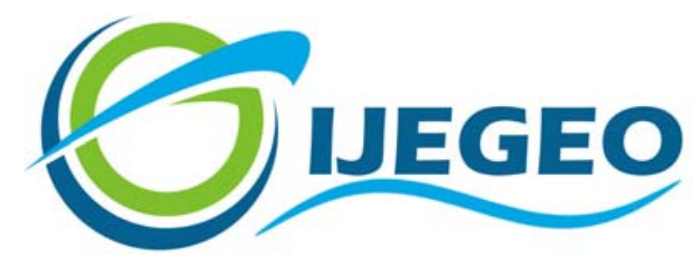

International Journal of Environment and Geoinformatics (IJEGEO) is an international, multidisciplinary, peer reviewed, open access journal.

\title{
Carbon Sequestration Analysis of dominant tree species using Geo-informatics Technology in Gujarat State (INDIA)
}

\author{
Ankit Arya, Shalini Negi, Jaydipsinh C. Kathota, Ajay N. Patel, \\ Manik H Kalubarme and J. K. Garg ${ }^{1}$
}

\section{Editors}

Prof. Dr. Cem Gazioğlu, Prof. Dr. Dursun Zafer Şeker, Prof. Dr. Ayşegül Tanık, Assoc. Prof. Dr. Şinasi Kaya

\section{Scientific Committee}

Assoc. Prof. Dr. Hasan Abdullah (BL), Assist. Prof. Dr. Alias Abdulrahman (MAL), Assist. Prof. Dr. Abdullah Aksu, (TR); Prof. Dr. Hasan Atar (TR), Prof. Dr. Lale Balas (TR), Prof. Dr. Levent Bat (TR), Assoc. Prof. Dr. Füsun Balık Şanlı (TR), Prof. Dr. Nuray Balkıs Çağlar (TR), Prof. Dr. Bülent Bayram (TR), Prof. Dr. Şükrü T. Beşiktepe (TR), Dr. Luminita Buga (RO); Prof. Dr. Z. Selmin Burak (TR), Assoc. Prof. Dr. Gürcan Büyüksalih (TR), Dr. Jadunandan Dash (UK), Assist. Prof. Dr. Volkan Demir (TR), Assoc. Prof. Dr. Hande Demirel (TR), Assoc. Prof. Dr. Nazlı Demirel (TR), Dr. Arta Dilo (NL), Prof. Dr. A. Evren Erginal (TR), Dr. Alessandra Giorgetti (IT); Assoc. Prof. Dr. Murat Gündüz (TR), Prof. Dr. Abdulaziz Güneroğlu (TR); Assoc. Prof. Dr. Kensuke Kawamura (JAPAN), Dr. Manik H. Kalubarme (INDIA); Prof. Dr. Fatmagül Kılıç (TR), Prof. Dr. Ufuk Kocabaş (TR), Prof. Dr. Hakan Kutoğlu (TR), Prof. Dr. Nebiye Musaoğlu (TR), Prof. Dr. Erhan Mutlu (TR), Assist. Prof. Dr. Hakan Öniz (TR), Assoc. Prof. Dr. Hasan Özdemir (TR), Prof. Dr. Haluk Özener (TR); Assoc. Prof. Dr. Barış Salihoğlu (TR), Prof. Dr. Elif Sertel (TR), Prof. Dr. Murat Sezgin (TR), Prof. Dr. Nüket Sivri (TR), Assoc. Prof. Dr. Uğur Şanlı (TR), Assoc. Prof. Dr. Seyfettin Taş (TR), Assoc. Prof. Dr. İ. Noyan Yılmaz (TR), Assist. Prof. Dr. Baki Yokeş (TR), Assist. Prof. Dr. Sibel Zeki (TR), Dr. Hakan Kaya (TR). 


\title{
Carbon Sequestration Analysis of dominant tree species using Geo-informatics Technology in Gujarat State (INDIA)
}

\author{
Ankit Arya ${ }^{1}$, Shalini Negi ${ }^{1}$, Jaydipsinh C. Kathota ${ }^{2}$, Ajay N. Patel ${ }^{2}$, \\ Manik H Kalubarme ${ }^{2, *}$, J. K. Garg ${ }^{1}$ \\ ${ }^{1}$ University School of Environment Management, Guru Gobind Singh Indraprastha University, \\ Dwarka, Sector 16-C, New Delhi, India \\ ${ }^{2}$ Bhaskaracharya Institute for Space Applications and Geo-Informatics (BISAG), Department of Science \& Technology, \\ Government of Gujarat, Gandhinagar, India \\ * Corresponding author. \\ Tel : +919909945040 \\ E-mail: mhkalubarme@gmail.com \\ Received: $\quad 01$ Feb 2017 \\ Accepted: 19 April 2017
}

\begin{abstract}
Comparative analysis of carbon store of three dominant tree species in planned green capital city of Gandhinagar and unplanned industrial town of Mahesana in Gujarat State, India was carried out using geoinformatics technology. The selected three major dominant tree species grown in these towns are Azadirachta indica, Acacia sp. and Cassia sp. The high spatial resolution Remote Sensing Satellite data from Indian Remote Sensing Satellite (IRS-Resourcesat-1) LISS-IV, Cartosat-1, and Google earth images were used in this study. The tree cover was categorized into dense and sparse on the basis of canopy cover observed on Satellite data. A grid of $1 \mathrm{~km} \mathrm{X} 1 \mathrm{~km}$ was created in GIS environment and superimposed on Cartosat-1 images. Random sample of $20 \%$ was selected for detailed tree count in the field and total tree count was estimated from these selected sample grids.
\end{abstract}

Total biomass and carbon sequestered in the major tree species have been estimated using a non-destructive method. The carbon stock estimated for three major tree species in Gandhinagar and Mahesana towns indicate that Azadirachta indica has maximum carbon sequestration potential as compared to Acacia sp. and Cassia sp. The maximum of carbon stock was present in Girth at Breast Height (GBH) size $>180 \mathrm{~cm}$ which is followed by GBH size 90 to $180 \mathrm{~cm}$. The total number of trees in Gandhinagar town is much higher as compared to Mahesana town; therefore estimated carbon store of dominant tree species in Gandhinagar town is very high as compared to Mahesana town which is more arid as compared to Gandhinagar.

Keywords: Carbon Sequestration, urban forestry, Total biomass, Girth at Breast Height (GBH), Carbon store, Remote Sensing (RS), Geographic Information System (GIS), Indian Remote Sensing Satellite

\section{Introduction}

Tree cover in urban areas around the world, is declining and impenetrable cover is increasing due to the demand of the area for development. The pace of urbanization is adversely affecting the green cover in the urban areas. With expanding urbanization in the twentieth century, the incorporation of trees into urban settlements has also expanded - to the point that the management of all trees within the urban area is considered a distinct discipline of forestry (Kaya et al., 2012). Additionally, these is a strong link between climate and health goals. Most of the mitigation measures for climate change investigated (including cleaner household-energy sources, less dependence on automobile transport etc.) would bring public health benefits (Saritrük et al., 2017). Gandhinagar town is also known as "Tree capital of India" because it has 54\% of green cover whereas Mahesana town is an industrial town with very less tree cover.

\section{Green India Mission (GIM)}

The Green India Mission (GIM), one of the missions under India's National Action Plan on Climate Change (NAPCC), hopes to sequester 4.3 crore tones of greenhouse gases each year by 2020 and absorb 6.35 percent of annual emissions. This action plan mentions about enhancing tree cover in over 2 lakh hectares in urban and peri-urban areas. It has been estimated that about 2.21 percent of the carbon 
stocks are stored in through urban tree cover, and the mission will promote greening forest patches threatened by expanding urban development, diffused planting and planting on institutional lands. The carbon enhancement is estimated about 2.2 lakh tones per year. This programme includes urban areas in Gujarat also. Thus, development of urban forestry may result into one tenth of above enhancement in Gujarat (MoEFCC, 2011).

\section{Carbon sequestration}

Carbon sequestration is the phenomenon for the storage of carbon dioxide $\left(\mathrm{CO}_{2}\right)$ from the atmosphere to mitigate global warming (Gazioğlu et al., 2015; Gazioğlu and Okutan, 2016). Plants store carbon as long as they live, in terms of live biomass. Trees perform important ecological function in sequestering carbon and reducing environmental pollution. Tree canopies provide a cooling effect on microclimate specifically by shading the ground surface and indirectly through transpiration (Subedi, et.al, 2010). Carbon sequestration is the long term storage of carbon in oceans, soils, vegetation (especially forests), and geological formations. Global warming is undoubtedly one of the major environmental issues of this century. Trees are carbon reservoir on earth. In nature, forest ecosystem act as a reservoir of carbon. They store huge quantities of carbon and regulate the carbon cycle by exchange of $\mathrm{CO}_{2}$ from the atmosphere. Forest ecosystem is one of the most important carbon sinks of the terrestrial ecosystem. It uptakes the carbon dioxide by the process of photosynthesis and stores the carbon in the plant tissues, forest litter and soils. Thus, forest ecosystem plays important role in the global carbon cycle by sequestering a substantial amount of carbon dioxide from the atmosphere. Carbon sequestration is a mechanism for the removal of carbon from the atmosphere by storing it in the biosphere (Gavali and Shaikh, 2016). The carbon sequestration and total biomass of tree species in a sacred grove at Nandghur in Pune District was estimated using non-destructive method (Hangarge, et al., 2012). A total number of 31 tree species were recorded in 5 hectors area of the sacred grove. The mean above and belowground organic carbon (tones/tree) and total organic carbon of each species were calculated. The calculated total organic carbon has been compared with allometric model.

\section{Carbon sequestration in Urban Ecosystems}

Urbanization drastically alters the ecosystems structure and functions, disrupts cycling of $\mathrm{C}$ and other elements along with water. It alters the energy balance and influences climate at local, regional and global scales. In 2008, urban population exceeded the rural population. In $2050,70 \%$ of the world population will live in urban centers. The number of megacities (10 million inhabitants) increased from three in 1975 to 19 in 2007, and is projected to be 27 in 2025. Rapid urbanization is altering the ecosystem $\mathrm{C}$ budget. Yet, urban ecosystems have a large $C$ sink capacity in soils and biota. Judicious planning and effective management can enhance $\mathrm{C}$ pool in urban ecosystems, and off-set some of the anthropogenic emissions. Principal components with regards to $\mathrm{C}$ sequestration include home lawns and turfs, urban forests, green roofs, park and recreational/sports facilities and urban agriculture (Rattan and Augustin, 2013).

Carbon storage and sequestration by urban trees in the United States was quantified to assess the magnitude and role of urban forests in relation to climate change. Urban tree field data from 28 cities and 6 states were used to determine the average carbon density per unit of tree cover (Nowak, et al., 2013). These data were applied to statewide urban tree cover measurements to determine total urban forest carbon storage and annual sequestration by state and nationally. Urban whole tree carbon storage densities average $7.69 \mathrm{~kg} \mathrm{C} \mathrm{m} \mathrm{m}^{2}$ of tree cover and sequestration densities average $0.28 \mathrm{~kg} \mathrm{C} \mathrm{m}^{2}$ of tree cover per year. Total tree carbon storage in U.S. urban areas (c. 2005) is estimated at 643 million tonnes ( $\$ 50.5$ billion value; $95 \%$ CI 1/4 597 million and 690 million tonnes) and annual sequestration is estimated at 25.6 million tonnes ( $\$ 2.0$ billion value; $95 \%$ CI $1 / 4$ 23.7 million to 27.4 million tonnes).

\section{Remote Sensing and GIS Applications for Urban Forestry}

Urban areas manage their urban forests by spatially referencing their trees and using this data to select sites, monitor tree health and 
growth, schedule trimming and treatment and set policies for environmental development. Geographic Information Systems (GIS) helps urban areas manage forestry projects efficiently and reduce management costs. GIS helps to create common database of diverse types of data for intelligent planning. A city's tree database may include tree location, species, diameter breast height (DBH), canopy width, condition, and development recordings etc. In addition to tree attribute data, the urban forest planner can include other pertinent features from the city's database such as streets, building, footprints, overhead and underground utilities, workforce areas, pest/disease quarantine zones, parks, and pending development areas.

GIS application can project different spatial data on different layers. Integrating different map layers into an urban tree management project enhances insight for decision making (Kaya and Gazioğlu, 2015). For example, the urban forest planner can easily localize zones with dense planting and zones with no planting, detect conflict cases for urban planting, measure the growth of the trees and estimate the probable effects by its evolution in the next years, exploit the current irrigation systems in the most ideal way, survey the tree canopy benefits and many other uses. Moreover a GIS methodology can also be a deserving tool for recording the people status estimation and will for urban forest.

Integrated Application of Remote Sensing and GIS for Carbon sequestration

Remotely sensed images are also important data sources for vegetation mapping and monitoring (Kaya, et al., 2015a,b). There are many conventional methods for quantification of sequestered carbon. The remote sensing approach can meet the requirements of carbon sequestration such as permanent sample plots (MacDicken, 1997) achieved by means of fixed coordinates, coupled with the systematic repetitive characteristic of most satellites. Tucker (1979), Richardson et al., (1983) and Christensen and Goudriaan (1993) demonstrated that the reflection of the red, green and near-infrared (NIR) radiation contains considerable information about plant biomass.

Steve et al., 2014 developed a very high resolution map of urban tree biomass, assessed the scale sensitivities in biomass estimation, compared results with lower resolution estimates, and explored the demographic relationships in biomass distribution across the City of Boston. The remote sensing data (including LiDAR-based tree height estimates) was integrated with field-based observations to map canopy cover and aboveground tree carbon storage at $\sim 1 \mathrm{~m}$ spatial scale. Mean tree canopy cover was estimated to be $25.5 \pm 1.5 \%$ and carbon storage was $355 \mathrm{Gg}(28.8 \mathrm{Mg} \mathrm{C}$ ha-1) for the City of Boston. Tree cover makes up a significant portion of land cover within the urban mosaic, with proportions in major US cities ranging from $\sim 10$ to $54 \%$ of land area (Nowak and Greenfield, 2012). However, 'urban' is a unique and inconsistently defined land cover that can store large stocks of carbon. For example, Raciti et al. (2012) compared three commonly used urban definitions and found that vegetation carbon stock density estimates ranged from $37 \pm 7$ to $66 \pm 8 \mathrm{Mg} \mathrm{C}$ ha -1 for the urban portions of the Boston metropolitan area.

Tree cover in Gandhinagar, the capital city of Gujarat, was assessed using remote sensing data of IRS-P6: LISS III of November 2011. The results of tree cover and tree population in Gandhinagar helped to develop an equation between tree cover and number of trees, which has been applied to estimate tree cover. A study based on remote sensing data has estimated 3075 ha of tree cover (dense + open) in Gandhinagar, which is equivalent to 8.67 lakh trees and $53.9 \%$ of geographical area and tree density (152 trees/ha) in Gandhinagar, the capital city of Gujarat, are the highest in India; thus Gandhinagar may be listed amongst the greenest cities in the world. The major (top three) tree species encountered in Gandhinagar are - neem (Azadirachta indica), Prosopis chilensis, deshi babool (A. nilotica), amaltas or garmalo (Casia fistula), (Singh, 2013). The study on the regression correlation analysis between GBH and Carbon stock was carried out in the major tree species of Dharoi Range, Gandhinagar Forest Division. The results 
indicated that GBH-Carbon Stock relationship showed relatively higher R2 values; and based on this a allometric model was developed which showed that GBH alone can safely be used to estimate carbon stock of major tree species in Dharoi Range (Jaiswal, et al., 2014).

Since the Kyoto Protocol, development of Carbon Sequestration (CS) strategies has become a global priority. The Intergovernmental Panel on Climate Change (IPCC) via its Good Practice Guidance Framework encourages the implementation of models and inventory measurement systems that are tailored to address national circumstances. Such models and systems should be driven by high resolution activity data which are disaggregated at sub-national level to fine grid-scales (Goetz et al., 2009). The review by Jeyanny et al., 2011 discusses the current utilization of RS and GIS technologies in CS management in various sectors. Niu and Duiker (2006) reported that Landsat imagery integrated into a GIS was used to identify hotspots (i.e., high CS capacity locations) for afforestation programs in the USA. The district-level carbon sequestration of wheat in Punjab State was estimated using MODIS satellite data. The calculated amount of carbon sequestration through remote sensing and GIS is $625.46 \mathrm{~kg} / \mathrm{ha}$. The total estimated value of carbon sequestration is 2168786.30 tonnes, calculated based on the biomass of the wheat. The highest amount of carbon Sequestration, in the district of Sangrur, was calculated to be 248068.69 tonne. The least carbon sequestration amongst the 17 districts of Punjab was found in NawanShahr (Tripathi et al., 2010).

\section{Objectives}

The major objectives of this study are as follows:

- Tree cover and density mapping using high spatial resolution Remote Sensing Satellite data and stratification and area estimation using GIS

- Total Tree biomass estimation of major tree species using nondestructive methods.
- Carbon sequestration estimation of major tree species in Gandhinagar and Mahesana towns

\section{Material and Methodology}

\section{Study Area}

Gandhinagar city is a head quarter of Gandhinagar District and Capital of Gujarat State. The district includes four talukas Mansa, Kalol, Dahegam and Gandhinagar. It is bounded by Mahesana, Patan, Sabarkantha and Banaskantha. All kinds of head offices of state government, secretariat of all departments, offices and residents of ministers of legislative assembly, residence of governor and other important offices are situated in Gandhinagar. The average elevation of Gandhinagar town is $81 \mathrm{~m}$ (266 feet). The city lies on the western bank of river Sabarmati. Gandhinagar city is also known as the "Tree capital of India" because of greenery. Gandhinagar town lies between $23.0^{\circ}$ to $23.6^{\circ} \mathrm{N}$ Latitude and $72.3^{\circ}$ to $73.7^{\circ}$ E Longitude. Total geographical area of town is 7685.59 ha from which sector area is selected for the study which is 2769.86 ha. The total population of the city as per census-2011 is $2,06,167$.

Mahesana Town lies between $23.15^{\circ}$ to $23.53^{\circ}$ $\mathrm{N}$ Latitude and $72.07^{\circ}$ to $72.26^{\circ}$ E Longitude. Total area of town is 3148.5 ha. Population in census 2011 is $1,84,991$. The climate of both locations is characterized by hot summer, cool winter, and general dryness except in the south - west monsoon months. The cold season from December to February is followed by the hot season from March to May. The period from June to September is the monsoon season followed by the post-monsoon period of October - November.

\section{Data used}

In this study, Indian Remote Sensing Satellite (IRS) LISS-IV data, Cartosat-1 PAN, Landsat TM and GIS data was used. Remote Sensing and GIS techniques were used for the analysis and interpretation of the satellite data. 
Remote Sensing (RS) satellite data

High resolution, Multi-temporal Satellite data of Indian Remote Sensing Satellite (Resourcesat-1) LISS-IV, Cartosat-1 Panchromatic data and Google images of different dates were used for mapping of tree cover in Gandhinagar and Mahesana towns (Table1). The high resolution satellite data used in this study covering Gandhinagar and Mahesana towns is given in Figure 2.
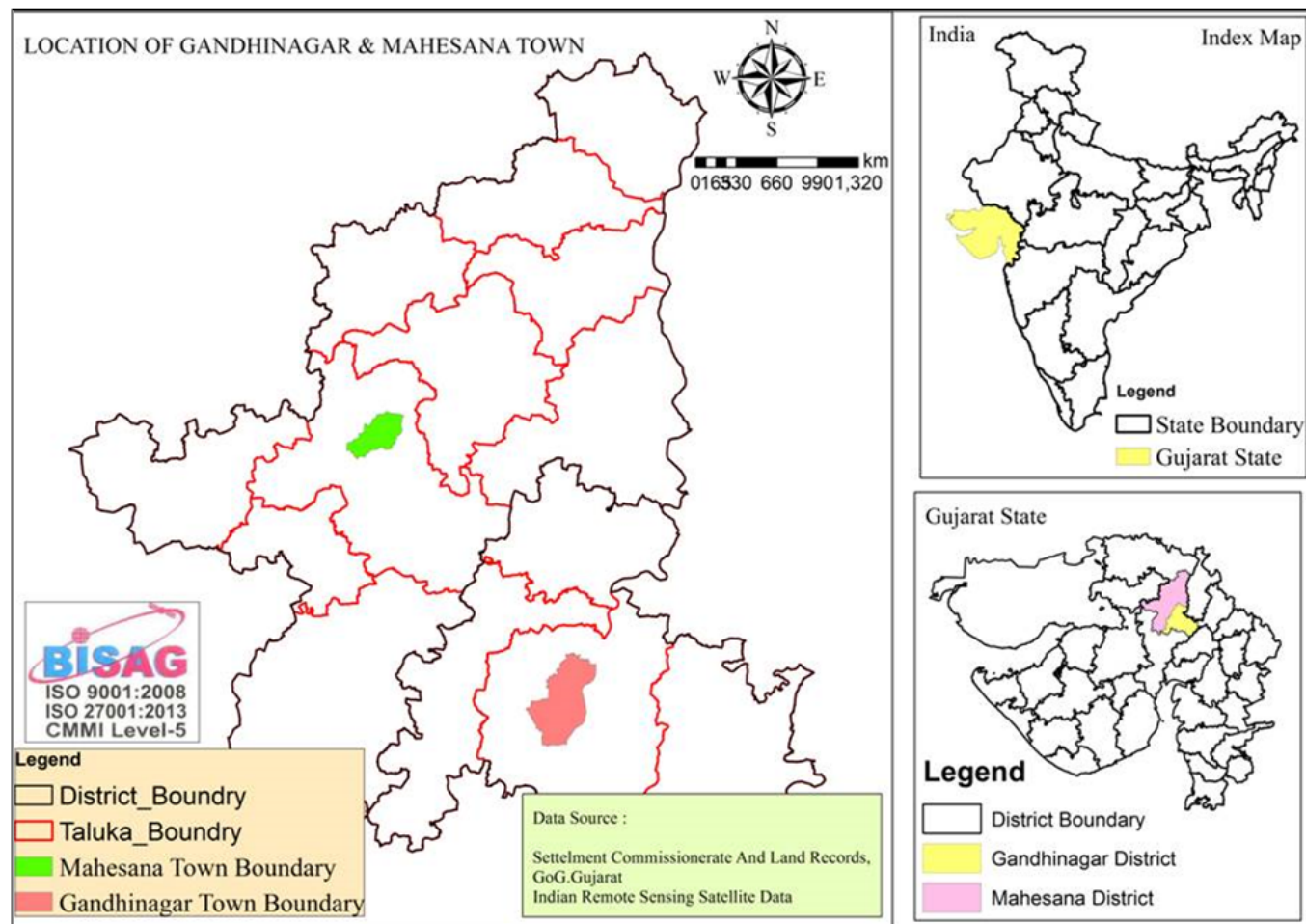

Fig 1. Location Map of Gandhinagar and Mahesana Towns in Gujarat State

Table 1: Details of Remote Sensing Satellite data used

\begin{tabular}{|c|c|c|c|c|c|}
\hline Sr.No. & Satellite & Sensor & Path/Row & Resolution & $\begin{array}{c}\text { Date of } \\
\text { Pass }\end{array}$ \\
\hline 1 & (IRS) Resourcesat-1 & LISS-IV & $093 / 056$ & $5.8 \mathrm{~m}$ & May-2014 \\
\hline 2 & (IRS) Resourcesat-1 & LISS-IV & $092 / 055$ & $5.8 \mathrm{~m}$ & April-2015 \\
\hline 3 & Cartosat-1 & PAN & $508 / 290$ & $2.5 \mathrm{~m}$ & April-2006 \\
\hline 4 & Cartosat-1 & PAN & $506 / 288$ & $2.5 \mathrm{~m}$ & April-2014 \\
\hline 5 & Earth View-2 & $\begin{array}{c}\text { Google } \\
\text { Image }\end{array}$ & - & $1 \mathrm{~m}$ & Feb 2014 \\
\hline 6 & Earth View-2 & $\begin{array}{c}\text { Google } \\
\text { Image }\end{array}$ & - & $1 \mathrm{~m}$ & Feb 2016 \\
\hline
\end{tabular}


Arya et al., IJEGEO, 4(2) 79-93 (2017)

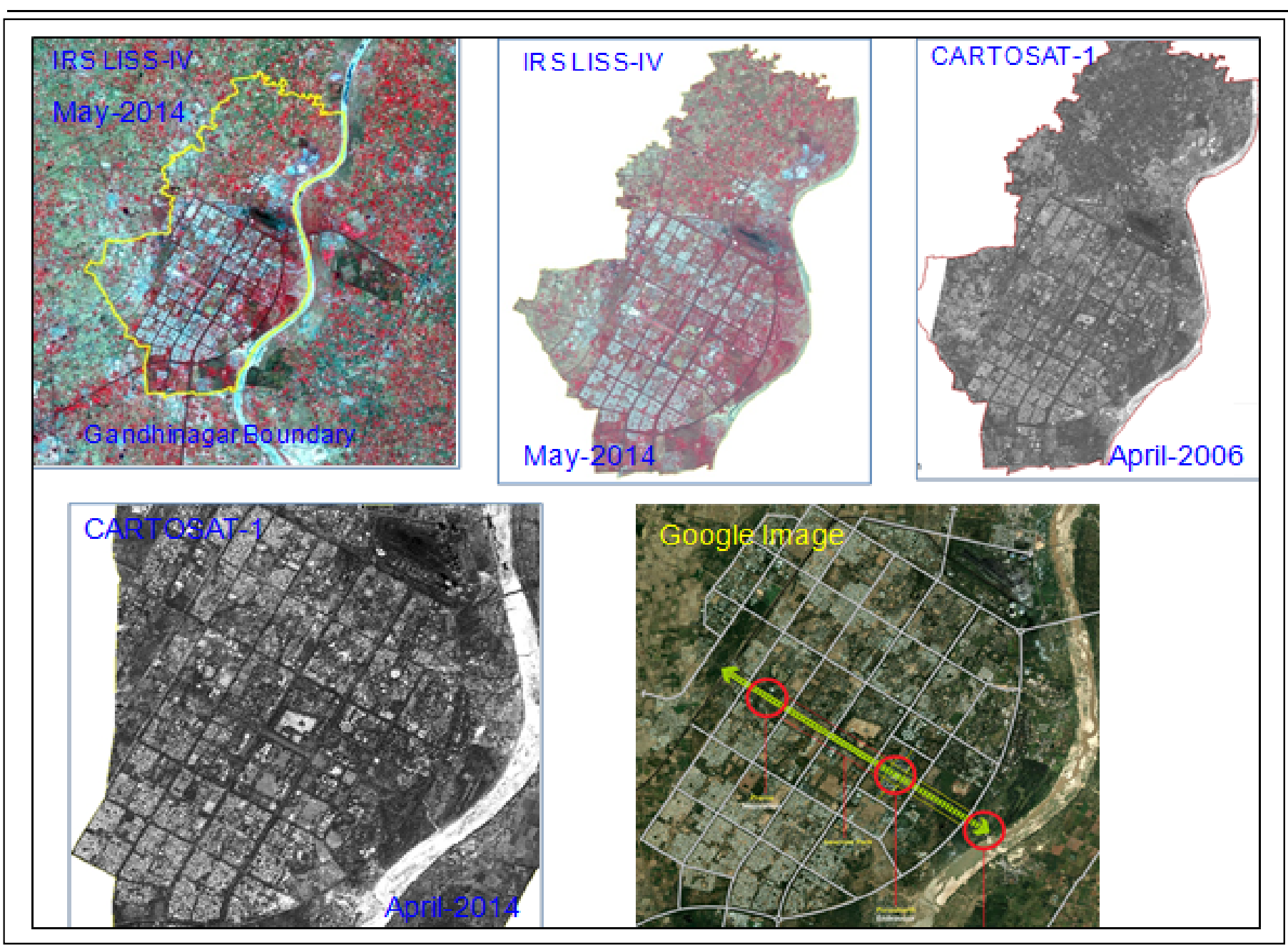

Fig. 2. High resolution Satellite data covering Gandhinagar and Mahesana towns 
Geographic Information System (GIS) data

The GIS data available with BISAG like: a) Town Boundaries, b) Transport Network, c) Water bodies and Drainage Network, d) Canal
Network etc. was used for preparation various base maps of the study area. One of the base maps of transport network in Gandhinagar and Mahesana towns is given in Fig 3.

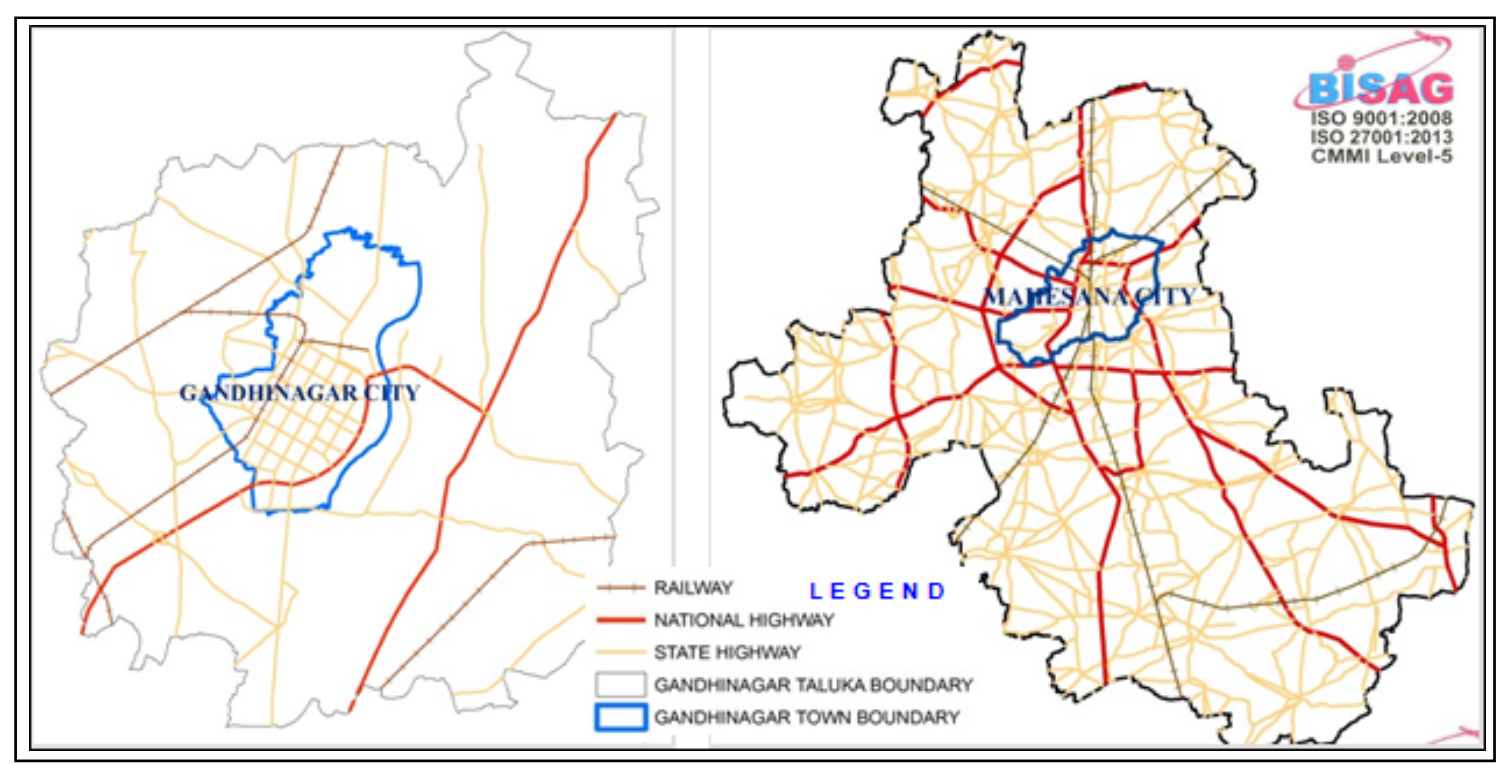

Fig. 3: Transport network in Gandhinagar and Mahesana Talukas in Gujarat State with town boundaries

\section{Field Data on Tree Species}

Field data on different tree species and their concentration in various parts of the two towns was collected. Geographic coordinates for the visited areas were also recorded using GPS along with tree species names. This GPS data was transferred on the satellite images for accurate area identification and tree density estimation. The field details like tree species name, their approximate density and tree cover, age etc. were also recorded.

Field photographs of various tree species and their density in different areas in two towns were also taken and the concept of geo-tagging was used for actual visualization of tree cover and density as seen on the high resolution Remote Sensing data. Geo-tagging of photographs helps to associate the photograph with the geographical location in the field. The locations of field observations and geo-tagged photographs superimposed on the Satellite data covering Gandhinagar town are given in Fig 4. The dominant tree species and their geographical locations in various sectors of Gandhinagar town are given in Fig 5.

\section{Tree cover mapping and total tree count using $R S$ data}

The tree cover in Gandhinagar and Mahesana towns was mapped using high resolution Cartosat-1 satellite data. For tree density mapping using Cartosat data, a grid of $1 \times 1 \mathrm{~km}$ was created using Fishnet feature in ArcGIS and superimposed on Cartosat-1 images covering two towns. The tree-cover was categorized into dense and sparse on the basis of canopy cover observed on Satellite data supported by field observations in selected areas. The tree cover mapped into dense and sparse categories in Gandhinagar and Mahesana towns is given in Fig 6. 


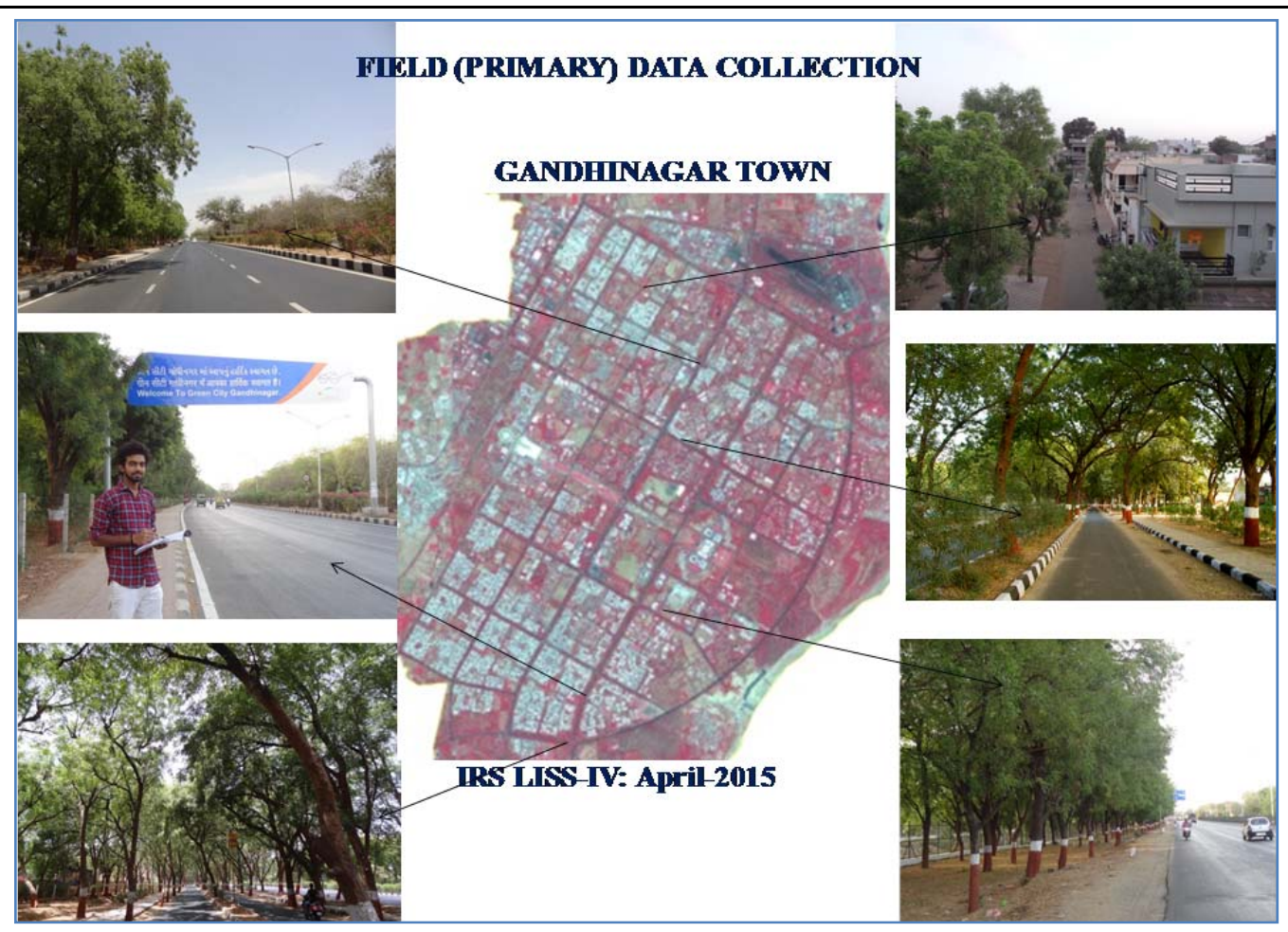

Fig 4. Field Photographs trees and their location on IRS LISS-IV data in Gandhinagar
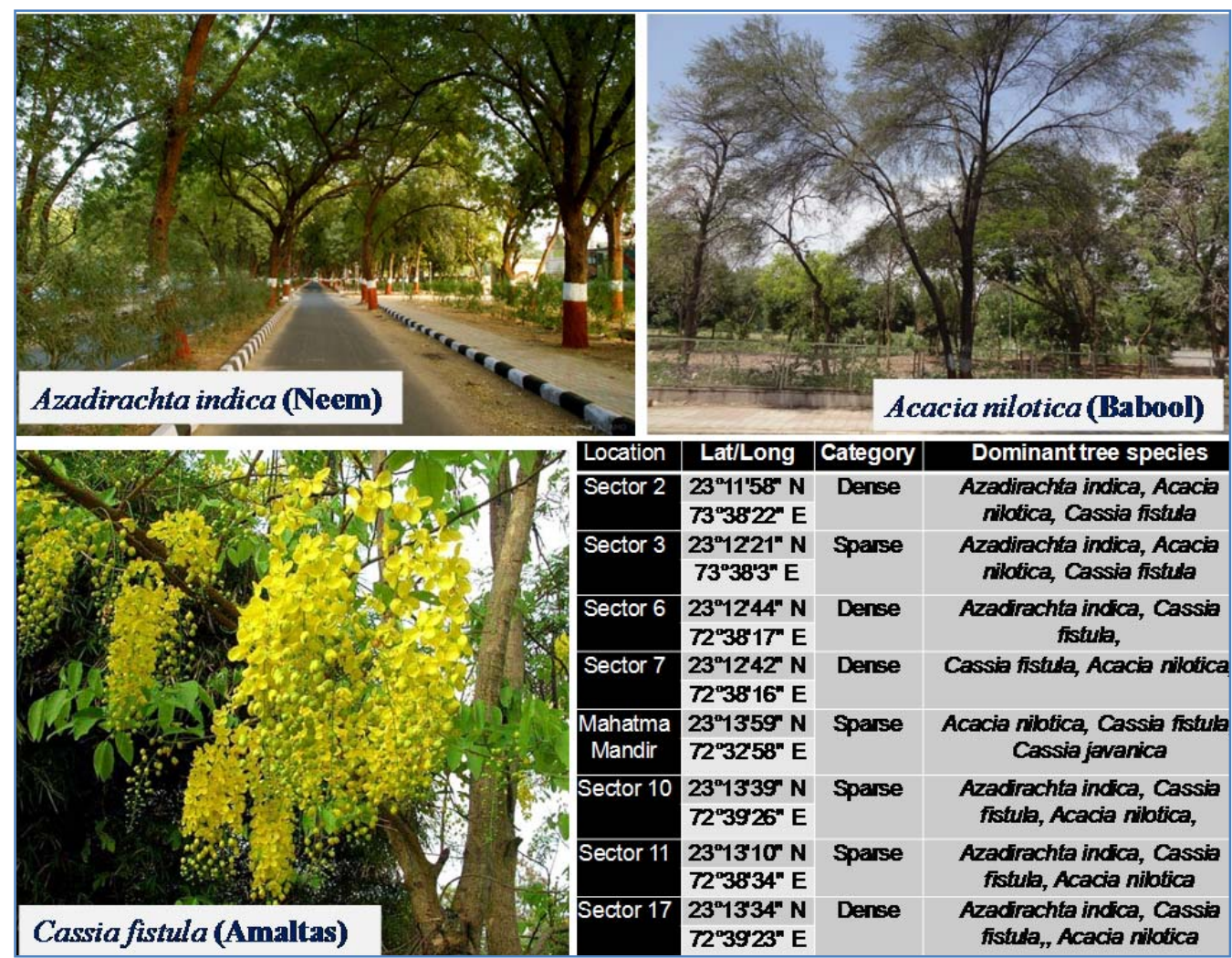

\begin{tabular}{|c|c|c|}
\hline Lat/Long & Category & Dominant tree species \\
\hline $\begin{array}{l}23^{\circ 1} 11^{158^{\prime \prime}} \mathrm{N} \\
73^{\circ} 38^{\prime 2} 22^{\prime \prime} \mathrm{E}\end{array}$ & Dense & $\begin{array}{c}\text { Azadirachta indica, Acacia } \\
\text { nilotica, Cassia fistula }\end{array}$ \\
\hline 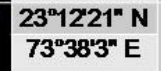 & Sparse & $\begin{array}{c}\text { Azadirachta indica, Acacia } \\
\text { nilotica, Cassia fistula }\end{array}$ \\
\hline $\begin{array}{l}23^{\circ 1244^{\prime \prime}} \mathrm{N} \\
72^{\circ} 38^{\prime 1} 17^{\prime \prime} \mathrm{E}\end{array}$ & Dense & $\begin{array}{l}\text { Azadirachta indica, Cassia } \\
\text { fistula, }\end{array}$ \\
\hline $\begin{array}{l}23^{\circ 1242^{n}} \mathrm{~N} \\
72^{\circ} 38^{\circ} 16^{\prime \prime} \mathrm{E}\end{array}$ & Dense & Cassia fistula, Acacia nilotica \\
\hline $\begin{array}{l}23^{\circ 1} 1359^{\prime \prime} \mathrm{N} \\
72^{\circ} 3258^{n} \mathrm{E}\end{array}$ & Sparse & $\begin{array}{c}\text { Acacia nilotica, Cassia fistula } \\
\text { Cassia jevarica }\end{array}$ \\
\hline $\begin{array}{l}23^{\circ 1} 13^{3} 39^{n} \mathrm{~N} \\
72^{\circ} 39^{\prime 2} 6^{\prime \prime} \mathrm{E}\end{array}$ & Sparse & $\begin{array}{c}\text { Azadrachta indica, Cassia } \\
\text { fistula, Acacia nilotica, }\end{array}$ \\
\hline $\begin{array}{l}23^{\circ} 13^{1} 10^{\prime \prime} \mathrm{N} \\
72^{\circ} 38^{\circ} 34^{\prime \prime} \mathrm{E}\end{array}$ & Sparse & $\begin{array}{c}\text { Azadirachta indica, Cassia } \\
\text { fistula, Acacia nilotica }\end{array}$ \\
\hline $\begin{array}{l}23^{\circ 133} 34^{n} \mathrm{~N} \\
72^{\circ} 39^{\prime \prime 2} \mathrm{E}\end{array}$ & Dense & $\begin{array}{l}\text { Azadirachta indica, Cassia } \\
\text { fistula, Acacia nilotica }\end{array}$ \\
\hline
\end{tabular}

Fig 5. Dominant tree species and their Geographic location in Gandhinagar 


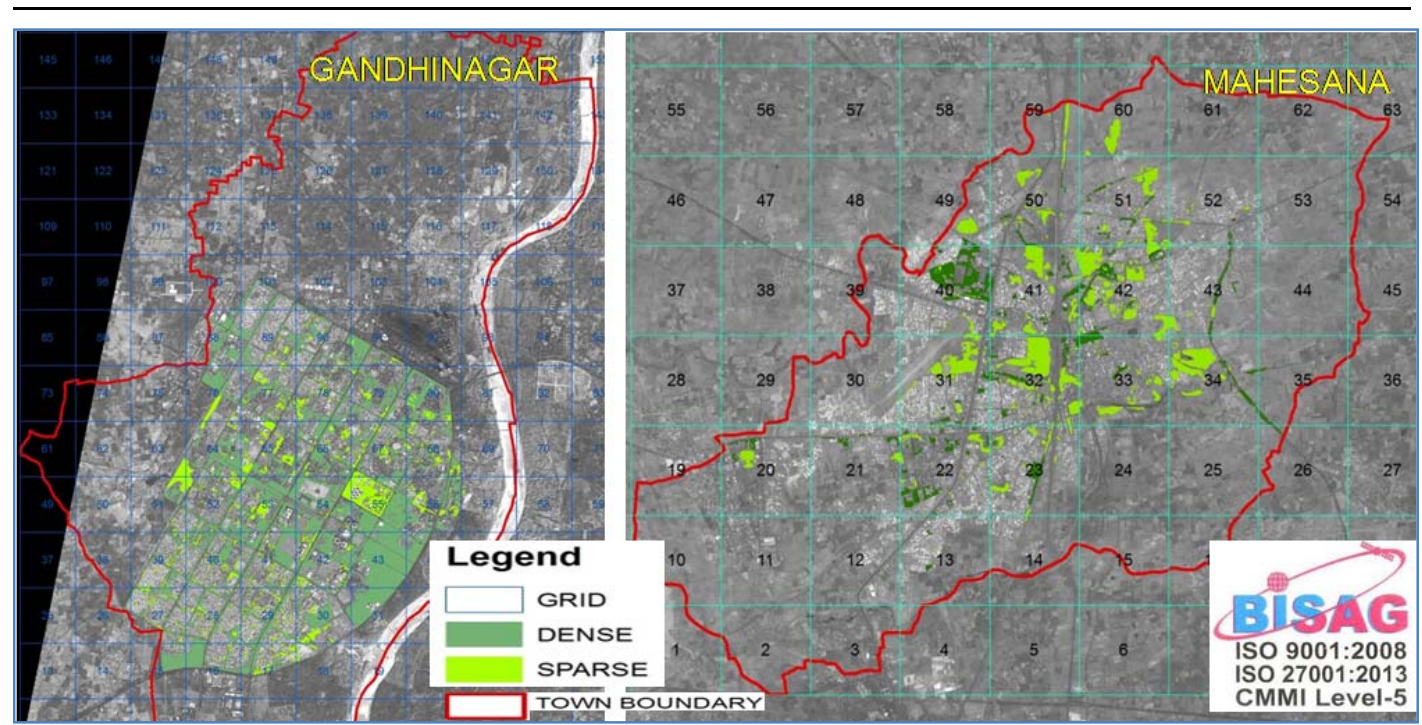

Fig 6. Tree cover density mapping using Cartosat-1 data in Gandhinagar and Mahesana

quadrat method was used to measure the $\mathrm{GBH}$,

The total number of grids in each city was counted and grids having more than $50 \%$ tree cover were selected on the basis of their category i.e. dense and sparse. It was observed that there were 35 grids having tree cover in Gandhinagar town out of which 30 grids were having dense and 5 grids were having sparse tree cover. From these grids a random sample of $20 \%$ were selected, therefore 6 grids from dense and 1 grid from sparse category were selected for actual tree cover count in the field. Similarly there were 11 grids were having more than $50 \%$ tree cover in Mahesana town out of which 7 grids were dense and 4 grids were sparse. From these grids a random sample of $20 \%$ was selected, therefore 2 grids from dense and 1 grid from sparse category were selected for actual tree cover count in the field. The actual tree count in the field was carried out in both the towns and from this data, mean for dense and sparse tree cover categories was computed and it was used to calculate total tree count for dense and sparse categories in both the towns.

Measurement of Tree Height and Girth at Breast Height (GBH)

The measurement of tree height and Girth at Breast Height (GBH) of dominant tree species was carried out using non-destructive methods. From $1 \mathrm{~km} \mathrm{X} 1 \mathrm{~km}$ grids, $10 \%$ sample grids were selected for laying quadrats and this above ground biomass (AGB) and below ground biomass (BGB) of dominant species. The tree height was measured using Clinometer and $\mathrm{GBH}$ was measured using measuring tape (Fig 7). The formula used to compute tree height is as follows:

$$
\text { Tree Height }=H+D * \tan (A)
$$

Where,

$\mathbf{H}=$ Height of clinometer to floor base,

$\mathbf{D}=$ distance of clinometer to tree and

$\mathbf{A}=$ angle taken from clinometer reading

Estimation of Above Ground Biomass (AGB)

The AGB of trees includes the whole plant parts outside the soil. The biomass of trees was estimated on the basis of GBH (Girth at Breast Height) and tree height. The random sampling method was used for sampling the trees for estimation of above ground biomass. The GBHs of trees having diameter greater than 50 $\mathrm{cm}$ were measured directly by measuring tape and height of the trees were measured by clinometers as mentioned earlier. The above ground biomass of trees was estimated on the basis of Girth at Breast Height (GBH) and tree height. Quadrant method was used to measure the GBH, above ground biomass (AGB) and 
below ground biomass (BGB) of dominant species. Equations for biomass usually include information on trunk Girth at breast height $\mathrm{GBH}$ (in $\mathrm{cm}$ ), total tree height $\mathrm{H}$ (in $\mathrm{cm}$ ), and wood density (in $\mathrm{g} / \mathrm{cm}^{3}$ ). The unit of the AGB estimated from the equation is kilogram $(\mathrm{kg})$. AGB is calculated using the following formula:

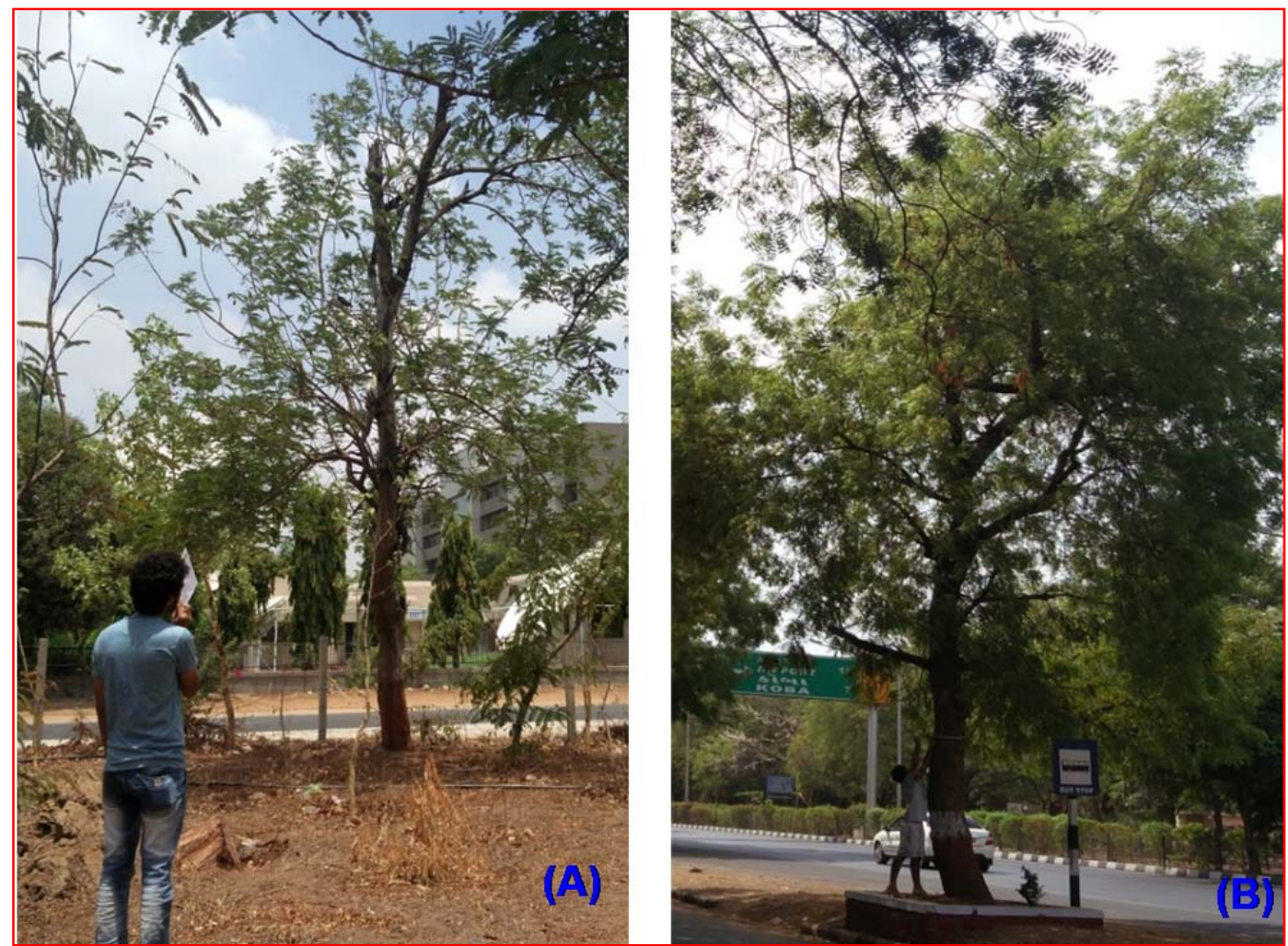

Fig 7. (A) Measurements of Tree Height using Clinometer and (B) GBH using Measuring tape

$$
\begin{aligned}
\operatorname{AGB}(\mathrm{g} / \text { tree })= & \text { Volume of tree }\left(\mathrm{cm}^{3}\right) \times \text { Wood density }\left(\mathrm{g} / \mathrm{cm}^{3}\right) \\
& =\pi \mathrm{r}^{2} \mathrm{H}\left(\mathrm{cm}^{3}\right) \times \text { Wood density }\left(\mathrm{g} / \mathrm{cm}^{3}\right) \\
& =(\mathrm{GBH})^{2} / 4 \pi \times \mathrm{H} \times \text { Wood density }\left(\mathrm{g} / \mathrm{cm}^{3}\right)
\end{aligned}
$$

Where,

$\mathbf{r}=$ radius of the tree $($ in $\mathrm{cm})=\mathrm{GBH} / 2 \pi$

$\mathbf{H}=$ Height of the tree (in $\mathrm{m}$ )

Radius of the tree is calculated from GBH of tree, the wood density of tree species was unavailable; therefore, the standard average

value $0.6 \mathrm{gm} / \mathrm{cm} 3$ were taken (Warran and Patwardhan, 2009). 


\section{Estimation of Below Ground Biomass (BGB)}

The Below Ground Biomass (BGB) includes all biomass of live roots excluding fine roots having $<2 \mathrm{~mm}$ diameter. The BGB has been calculated by multiplying AGB by 0.26 factors as the root: shoot ratio. BGB is calculated by using following formula (MacDicken, 1997):

\section{BGB $($ ton $/$ tree $)=$ AGB $($ ton $/$ tree $) \times 0.26$}

Estimation of Total Biomass (TB)

Total biomass of trees was calculated by sum of AGB and BGB of trees. The total Biomass of trees was calculated using following equation (MacDicken, 1997):

\section{Total Biomass $($ ton $/$ tree $)=$ AGB + BGB}

\section{Estimation of Carbon Storage}

Generally, for any plant species $50 \%$ of its biomass is considered as carbon. The carbon of trees was calculated using following equation (Vieilledent et al., 2012).

\section{Carbon store $=$ Biomass $\times \mathbf{5 0} \%$ \\ or \\ $=$ Biomass $/ 2$}

Based on above formulas carbon store of dominant tree species in Gandhinagar and Mahesana towns was estimated.

\section{Results and Discussions}

Estimation of Total number of Tree in Gandhinagar and Mahesana Towns

The tree cover in Gandhinagar and Mahesana towns was mapped into dense and sparse categories using satellite data in each grid of 1 $\mathrm{km}$ X $1 \mathrm{~km}$. The total tree count in Gandhinagar and Mehsana towns was estimated using random sampling procedure. The total number grids of $1 \times 1 \mathrm{~km}$ in dense and sparse tree cover categories were counted and 20 per cent random samples were selected for actual tree count in each grid in the field. From this field count of trees in the selected grids from dense and sparse category, the mean value for each category was computed. The total number trees in dense and category was computed by multiplying the mean value by the total number of grids. The total number of trees in Gandhinagar and Mahesana towns was estimated by adding the total trees in dense and sparse categories. The details of sampling grids, tree count and estimated total number of trees in Gandhinagar and Mahesana towns are given Table-2.

Table 2. Details of sampling grids and estimated total number of trees in Gandhinagr and Mahesana

\begin{tabular}{|c|c|c|c|c|c|c|c|c|}
\hline & \multicolumn{4}{|c|}{ GANDHINAGAR } & \multicolumn{4}{|c|}{ MAHESANA } \\
\hline & \multicolumn{2}{|c|}{ Dense } & \multicolumn{2}{|c|}{ Sparse } & \multicolumn{2}{|c|}{ Dense } & \multicolumn{2}{|c|}{ Sparse } \\
\hline Grids & \multicolumn{2}{|c|}{30} & \multicolumn{2}{|c|}{5} & \multicolumn{2}{|c|}{7} & \multicolumn{2}{|c|}{4} \\
\hline $20 \%$ & \multicolumn{2}{|c|}{6} & \multicolumn{2}{|c|}{1} & \multicolumn{2}{|c|}{2} & \multicolumn{2}{|c|}{1} \\
\hline & Grid No & $\begin{array}{c}\text { Tree } \\
\text { Count }\end{array}$ & $\begin{array}{l}\text { Grid } \\
\text { No }\end{array}$ & $\begin{array}{c}\text { Tree } \\
\text { Count }\end{array}$ & $\begin{array}{l}\text { Grid } \\
\text { No }\end{array}$ & $\begin{array}{c}\text { Tree } \\
\text { Count }\end{array}$ & $\begin{array}{c}\text { Grid } \\
\text { No }\end{array}$ & $\begin{array}{l}\text { Tree } \\
\text { Count }\end{array}$ \\
\hline & 16 & 6536 & 77 & 7932 & 50 & 7946 & 41 & 5986 \\
\hline & 40 & 11720 & & & 32 & 7388 & & \\
\hline & 65 & 6990 & & & & & & \\
\hline & 80 & 6970 & & & & & & \\
\hline & 56 & 10382 & & & & & & \\
\hline & 29 & 8582 & & & & & & \\
\hline \multicolumn{2}{|c|}{ Total Trees } & 51180 & & 7932 & Total & 15334 & & 5986 \\
\hline \multicolumn{2}{|c|}{ Mean } & 8530 & & 7932 & mean & 7667 & & 5986 \\
\hline & $\begin{array}{l}30 \mathrm{X} \\
8530\end{array}$ & 255900 & $\begin{array}{c}5 X \\
7932\end{array}$ & 39660 & $\begin{array}{c}7 X \\
7667\end{array}$ & 53669 & $\begin{array}{c}4 X \\
5986\end{array}$ & 23944 \\
\hline G. Total & \multicolumn{4}{|c|}{$255900+39660=295560$} & \multicolumn{4}{|c|}{$53669+23944=77613$} \\
\hline
\end{tabular}


Table-2 indicates that the estimated total number of tree in Gandhinagar and Mahesana towns are 2,95,560 and 77,613 respectively. This result indicates that Gandhinagar town has almost four times more number of trees as compared to Mahesana town. During field data collection it was also observed that Azardirichta indica, Acacia sp. and Cassia sp. were dominant tree species in both the towns.

\section{Estimation of Total Biomass and Total Carbon} Stock of Dominant Tree Species

The Girth at Breast Height (GBH) of major tree species was measured in the field and it was categorized into three classes based on the GBH size like 0-90 cm, $90-180 \mathrm{~cm}$ and $>180$ $\mathrm{cm}$. The Total Biomass (TB) of trees was estimated on the basis of various formulae given in sections 3.2.5, 3.2.6, 3.2.7 and 3.2.8. The dominant tree species in both the towns were classified into three classes based on their GBH size namely, $0-90 \mathrm{~cm}, 90-180 \mathrm{~cm}$ and $>$ $180 \mathrm{~cm}$. The carbon store of these dominant tree species was computed based on the formula given in section 3.2.9. The estimated GBH class-wise number of trees, total biomass and Carbon Store of dominant tree species in Gandhinagar and Mahesana towns are given in Table-3 and Table-4, respectively.

Table 3. Estimated GBH Class-wise number of trees, Total Biomass and Carbon Store of dominant tree species in Gandhinagar town

\begin{tabular}{|c|c|c|c|c|c|c|}
\hline \multirow{2}{*}{$\begin{array}{l}\text { Dominant } \\
\text { Species }\end{array}$} & \multirow{2}{*}{$\begin{array}{l}\text { Total } \\
\text { tree } \\
\text { count }\end{array}$} & \multicolumn{3}{|c|}{ No of Trees in each GBH Size } & \multirow{2}{*}{$\begin{array}{l}\text { Total } \\
\text { Biomass } \\
\text { (tons) }\end{array}$} & \multirow{2}{*}{$\begin{array}{l}\text { Carbon } \\
\text { Store } \\
\text { (tons) }\end{array}$} \\
\hline & & $0-90 \mathrm{~cm}$ & $90-180 \mathrm{~cm}$ & $>180 \mathrm{~cm}$ & & \\
\hline $\begin{array}{l}\text { Azadirachta } \\
\text { indica }\end{array}$ & 192114 & 43679 & 64038 & 84397 & 891873.85 & 445936.92 \\
\hline Acacia sp. & 44334 & 10360 & 14778 & 19196 & 83046.31 & 96895.72 \\
\hline Cassia sp. & 11526 & 1569 & 3842 & 6115 & 62265.23 & 31132.62 \\
\hline Total & & & & & & 573965.26 \\
\hline
\end{tabular}

Table-4: Estimated GBH Class-wise number of trees, Total Biomass and Carbon Store of dominant tree species in Mahesana town

\begin{tabular}{|l|l|l|l|l|l|l|}
\hline \multirow{2}{*}{$\begin{array}{l}\text { Dominant } \\
\text { Species }\end{array}$} & \multirow{2}{*}{$\begin{array}{l}\text { Total tree } \\
\text { count }\end{array}$} & \multicolumn{2}{|l|}{ No of Trees in each GBH Size } & $\begin{array}{l}\text { Total } \\
\text { Biomass } \\
\text { (tons) }\end{array}$ & $\begin{array}{l}\text { Carbon } \\
\text { Store } \\
\text { (tons) }\end{array}$ \\
\hline $\begin{array}{l}\text { Azadirachta } \\
\text { indica }\end{array}$ & 54329 & 9351 & 18109 & 26869 & 277214.80 & 138607.40 \\
\hline Acacia sp. & 7761 & 703 & 2587 & 4471 & 44869.71 & 22434.86 \\
\hline Cassia sp. & 1552 & 115 & 517 & 919 & 9179.28 & 4589.62 \\
\hline Total & & & & & & 165631.88 \\
\hline
\end{tabular}

Comparative analysis of carbon sequestration in Gandhinagar and Mahesana town

It was observed that the total number of trees in Gandhinagar town is almost 4-times more as compared to Mahesana town; the estimated carbon store is almost 3.5-times higher as compared to Mahesana town. The total carbon stock of the major trees species in Gandhinagar town is $573,965.3$ tons and in Mahesana town is 165,631.9 tons. Azadirachta indica shows maximum carbon stock as compared to other two species namely Acacia sp. and Cassia sp. in both the towns mainly because of large tree count. The maximum of carbon stock was present in $\mathrm{GBH}$ size $>180 \mathrm{~cm}$ which is followed by $\mathrm{GBH}$ size 90 to $180 \mathrm{~cm}$ and girth class 0 to $90 \mathrm{~cm}$. 


\section{Conclusions}

The analysis of carbon sequestration of three dominant tree species in Gandhinagar and Mahesana towns in Gujarat State, India was carried out using geo-informatics technology. The high resolution data from Indian Remote Sensing Satellite (IRS-Resourcesat-1) LISS-IV, Cartosat-1, and Google earth images were used to map tree cover in both the towns. The major dominant tree species observed in Gandhinagar and Mahesana towns are Azadirachta indica, Acacia sp. and Cassia sp. The tree cover in two towns was categorized into dense and sparse on the basis of canopy cover observed on Satellite data. A grid of $1 \times 1 \mathrm{~km}$ was superimposed on Cartosat-1 images and a random sample of 20 $\%$ was selected for detailed tree count in the field. The total tree count in both the towns was estimated from these selected sample grids. Field data on different tree species and their concentration in various parts of the two towns was collected and GPS data was transferred on the satellite images for accurate area identification and tree density estimation. The Carbon store of dominant tree species in Gandhinagar and Mahesana town was calculated using non-destructive method. The major conclusions of this study are as follows:

- $\quad$ The High resolution satellite data from Cartosat-1 (spatial resolution $2.5 \mathrm{~m}$ ) and IRS LISS-IV (spatial resolution $5.8 \mathrm{~m}$ ) has been effectively used for mapping tree density based on canopy cover. A stratified random sampling with $1 \mathrm{~km} \mathrm{X} 1 \mathrm{~km}$ grid size and sampling fraction of $20 \%$ was used for estimating total tree count in Gandhinagar and Mahesana towns.

- The carbon stock of major tree species has been estimated by non-destructive method. The carbon stock estimated for three major tree species in Gandhinagar and Mahesana towns indicate that Azadirachta indica has maximum carbon sequestration potential as compared to Acacia $s p$. and Cassia sp.

- The maximum of carbon stock was present in GBH size $>180 \mathrm{~cm}$ which is followed by $\mathrm{GBH}$ size 90 to $180 \mathrm{~cm}$ and girth class 0 to $90 \mathrm{~cm}$.

- The total number of trees in Gandhinagar town is much higher as compared to Mahesana town, therefore estimated carbon store of dominant tree species in Gandhinagar town accounts more as compared to Mahesana town which is more arid as compared to Gnadhinaagar.

\section{Acknowledgements}

The authors express their sincere thanks to Shri T. P. Singh, Director, Bhaskarcharya Institute for Space Applications and Geo-informatics (BISAG), Department of Science \& Technology, Government of Gujarat, Gandhinagar for his encouragement and guidance to conduct this study. We also express our sincere thanks and gratitude to Prof. Anubha Kaushik, Dean, University School of Environment Management (USEM), Guru Gobind Singh Indraprastha University, Dwarka, Sector 16-C, New Delhi, India for the continuous encouragement and valuable advice

\section{References}

Christensen, S., and Goudriaan, J., 1993. Deriving Light Interception and Biomass from Spectral Reflection ratio. Remote Sensing Environment 48:87-95.

Gavali, R. S. And Shaikh, H. M. Y, 2016. Estimation of Carbon Storage in the Tree Growth of Solapur University Campus, Maharashtra, India. International Journal of Science and Research (IJSR), Vol.5 (4): 2364-2367.

Gazioğlu, C. and Okutan, V. (2016). Underwater Noise Pollution at the Strait of Istanbul (Bosphorus), International Journal of Environment and Geoinformatics (IJEGEO), Vol:3(3): 26-39.

Gazioğlu, C., Müftüoğlu, AE., Demir, V., Aksu, A. and Okutan, V. (2015). Connection between Ocean Acidification and Sound Propagation, International Journal of Environment and Geoinformatics (IJEGEO), Vol.2(2):16-26.

Goetz, S.J., Baccini, A., Laporte, NT., Johns, T., Walker, W., Kellndorfer, J., Houghton, 
RA. and Sun, M. (2009). Mapping and monitoring carbon stocks with satellite observations: A comparison of methods. Carbon Bal. Manag., 4: 2: 1-7.

Hangarge, L. M., Kulkarni, D. K., Gaikwad, V. B., Mahajan, D. M., and Chaudhari, N. (2012). Carbon Sequestration potential of tree species in Somjaichi Rai (Sacred grove) at Nandghur village, in Bhor region of Pune District, Maharashtra State, India. Annals of Biological Research, Vol.3 (7):.3426-3429.

Jaiswal, Dharmesh G., Patel, Chirag N., Patel, Yogesh B., Mankad, Archana U., and Pandya, Himanshu A., 2014. Regression Correlation Analysis between GBH and Carbon Stock of Major Tree Species in Dharoi Range, Gandhinagar Forest Division, India. International Journal of Innovative Research in Science, Engineering and Technology, Vol. 3(11): 17146- 17149.

Jeyanny, V., S.K. Balasundram and M.H.A. Husni, 2011. Geo-Spatial Technologies for Carbon Sequestration Monitoring and Management. American Journal of Environmental Sciences 7 (5): 456-462.

Kaya Ş., Gazioğlu C., Sertel E. , Şeker D.Z., Alganc1 U. (2015a). Rapid Determination Of Land Use/Cover Changes Using Data Fusion", ACRS 2015: The 36 th Asian Conference on Remote Sensing "Fostering Resilient Growth in Asia”, Metro Manila, Philippines, 19-23 September 2015: 1-5.

Kaya, H. and Gazioğlu, C. (2015). Real Estate Development at Landslides, International Journal of Environment and Geoinformatics (IJEGEO), Vol.2(1):62-71.

Kaya, Ş., Başar, UG., Karaca, M. and Şeker, DZ. (2012). Assessment of urban heat islands using remotely sensed data, Ekoloji, Vol. 21(84):107-113.

Kaya, Ş., Osgouei, PE., Alganc1, U., Şeker, DZ. And Gazioğlu, C. (2015b). Evaluation Of Vegetation Density Changes In Suburban Area: A Case Study Of Istanbul Metropolitan Area, ACRS 2015: The 36 th Asian Conference on Remote Sensing "Fostering Resilient Growth in Asia", Quezon City, Metro Manila, Philippines, 19-23 September 2015:1-6.

Lal, Rattan, Augustin, Bruce (Eds.), 2012. Carbon Sequestration in Urban Ecosystems.

MacDicken, K.G., "A Guide to Monitoring Carbon Storage in Forestry and

92
Agroforestry Projects", Winrock International Institute for Agriculture Development, USA, 1997.

Niu, X. and Duiker, SW. (2006). Carbon sequestration potential by afforestation of marginal agricultural land in the Midwestern U.S. For. Ecol. Manag., 223: 415-427.

Nowak, D.J. and Greenfield, E.J., 2012. Tree and impervious cover change in US cities. Urban For Urban Green 2012; 11(1): 21-30.

Nowak, D.J. and Greenfield, E.J., Hoehn, Robert E. and Lapoint, Elizabeth, 2013. Carbon storage and sequestration by trees in urban and community areas of the United States. Environmental Pollution, 178: 229236.

Raciti, S.M., Hutyra, L.R., Rao, P. and Finzi, A.C. (2102). Soil and vegetation carbon in urban ecosystems: the importance of importance of urban definition and scale. Ecol Appl 2012, 22(3): 1015-35.

Richardson,J.,J., H. Everitt, and H.W. Gausman. 1983. Radiometric Estimation of Biomass and N-Content of Alicia Grass. Remote Sensing Environment. 13:179-184.

Sarıtrük, B., Sivri, N. and Şeker, DZ. (2017). A Study To Determine Level Of Awareness About Health And Carbon Footprint Among Geomatics Engineers In Turkey, Fresenius Environmental, Vol: 26(1):156-161.

Singh, H. S. (2013). Tree density and canopy cover in the urban areas in Gujarat, India. CURRENT SCIENCE, Vol. 104 (10): 1294-1299.

Singh, H. S. (2013). Tree wealth in the nonforest areas of Gujarat. Trees outside Forest (TOF) - Third Tree Counting-2013, Gujarat Forest Department, Gandhinagar, pp. 3-8.

Steve M. Raciti, Lucy R. Hutyra, and Jared D. Newell (2014). Mapping carbon storage in urban trees with multi-source remote sensing data: Relationships between biomass, land use, and demographics in Boston neighborhoods. Science of the Total Environment 500-501: 72-83.

Subedi, B. P., Pandey, S. S., Pandey, A., Rana, E. B., Bhattarai, S., Banskota, T. R., Charmakar, S., and Tamrakar, R. (2010.). Guidelines formeasuring carbon stocks in community-managed forests. ANSAB, FECOFUN, ICIMOD, NORAD..69p.

Tripathi, Shashikant, Soni, Sandeep Kr., Maurya, Abhisek Kr., and Soni, Pradeep Kr. 
(2010). Calculating carbon sequestration using remote sensing and GIS. Geospatial World, May 3, 2010, pp. $1-8$.

Tucker, C.J.1979. Red and Photographic Infrared Linear Combinations for Monitoring Vegetation. Elsevier North Holland Inc. 8:127-150.

Vieilledent, G., Vaudry, R., Andriamanohisoa, S. F., Rakotonarivo, O. S., Randrianasolo, H. Z., Razafindrabe, H. N., Rakotoarivony,
C. B., Ebeling, J. and Rasamoelina, M. (2012). A universal approach to estimate biomass and carbon stock in tropical forests using generic allometric models. Ecological Applications, 22 (2): 572-583.

Warran, A., and Patwardhan, A. (2009). Carbon sequestration potential of trees in and around Pune City. RANWA, Pune, India. 